\title{
Retracted: Soil shrinkage and consolidation study on flood embankments in swamp irrigation areas
}

\author{
Lusmeilia Afriani $^{a^{*}}$, Gatot Eko Susilo ${ }^{a}$, Sri Nawangrinia and Iswan ${ }^{a}$
}

${ }^{a}$ Civil Engineering Department, Universitas Lampung, Bandar Lampung,35145, Indonesia

\begin{tabular}{l}
\hline A R T I C L E I N F O \\
\hline Article history: \\
Received 10 November 2020 \\
Accepted 4 January 2021 \\
Available online \\
4 January 2021 \\
\hline Keywords: \\
Soil Shrinkage \\
Consolidation \\
Embankment \\
Swamp irrigation
\end{tabular}
\begin{abstract}
A B S T R A C T
Research in this paper discusses shrinking and consolidation of flood embankments soil in swamp irrigation areas. The flood embankments are made from swampy soil materials. The focus of this research is the reduction of dyke embankment height that occurs due to soil shrinkage and soil consolidation. Investigations about the time of consolidation and land subsidence that occurred on the embankment at certain periods after the embankment established were also carried out in this study. The research sites are some swamp irrigation areas in the Tulang Bawang Watershed, around NorthEast Lampung, Indonesia. This research was carried out by conducting laboratory tests on soil samples and field observations on the reduction in height of flood embankments in the study area. The research shows that the main cause of total decrease on the embankment is due to linear shrinkage, consolidation of soil under the embankment, an immediate subsidence, and the subsidence of the embankment themselves. Their contribution to total decrease of embankment is $42.51 \%, 34.48 \%$, $18.32 \%$, and $4.62 \%$, respectively. Results also indicate that the ratio between the percentage of embankment consolidation in downstream area happen faster than the one in upstream area of the river.
\end{abstract}

\section{Introduction}

Flood embankments on swamp irrigation are made by utilizing local soil by digging the soil on the right and left of the plan of the dike wall. This utilization of local soil is carried out in consideration of cost efficiency and easy access to material and technical implementation of the work (Afriani et al. 2008). On the other hand, flood protection dykes in swamp irrigation areas require special attention in relation to the decline or depreciation that will be experienced. Scientifically, the decline of flood embankment body due to the material forming it, was rare discussed by the public. Basically, if the reduction or depreciation is well considered in the design of the embankment, there will be cost savings in the construction process. Studies investigating the behavior of soil depreciation on flood embankments in swamp irrigation are an interesting special topic. Depreciation that occurs on the expansive or soft soils that form dikes will cause a decrease in the embankment body (Afriani 2014). Furthermore, the burden on the embankment will also cause a decrease in the embankment body due to consolidation on the embankment body itself and consolidation on the soil under the embankment. On the other hand, it is also necessary to consider an immediate settlement that occurs in the soil under the embankment. In addition, Kumor (2008) found that the main problem in the application of geo-technique in the field was

* Corresponding author.

E-mail addresses: afriani L@eng.unila.ac.id (L. Afriani) 
estimating depreciation due to post-consolidation on expansive soils. On the other hand, Izdebska-Mucha and Wójcik (2013) evaluated the volume depreciation in relation to changes in the water content and suggested that the water content must also be considered together with the nature of the soil material in the volume depreciation. In principle, the shrinkage limit is defined as a condition where the land mass does not change in volume when the water content decreases (Muntohar, 2005). For this reason, we need to know the volumetric shrinkage value $\left(V_{c}\right)$ of the soil. $V_{c}$ is the change in soil volume from initial volume until the soil no longer experiences shrinkage in the elongated direction.

In relation to the reduction, we also need to determine the linear shrinkage $\left(L_{s}\right)$, which is the decrease of soil which can occur due to the loading on it. This decrease is caused by elastic deformation of the soil in dry, wet or saturated soil conditions where the decrease does not occur with changes in water content. The magnitude of this reduction will depend on the shape and dimensions of the foundation and the type of material in which the foundation is placed Das (1995). In addition to the elastic deformation of the soil, the addition of a load over the surface can also cause the soil layer underneath to compress due to the release of water or air from the pore, which is called consolidation. The decline in the flood embankment will run over time. A decrease due to shrinkage (linear shrinkage) and an immediate settlement due to elastic deformation of the soil can be assumed to occur immediately. However, it needs to be examined specifically regarding the time of depreciation and the time of immediate settlement.

The research in this paper discusses the shrinking and decreasing behavior of the soil on flood dyke embankments which made from swampy soils in swamp irrigation areas. The focus of this research is the reduction of dyke embankment height that occurs due to soil shrinkage and soil consolidation. Investigations about the time of consolidation and soil subsidence that occurred at certain periods after the embankment established were also carried out in this study. The research sites are some swamp irrigation areas in the Tulang Bawang Watershed, around North-East Lampung, Indonesia.

\section{Materials and methods}

The soil sample used in this study is swamp soil that exists between Tulang Bawang River and Pidada River, Tulang Bawang Regency in Indonesia as shown in Fig. 1. Three soil sampling and observations were carried out at 3 places located within the scope of the Pidada River Basin in Indonesia. They are Aji Mesir, Batu Ampar and Rawa Ragil points. While other samples were taken at the Sumber Sari and Gedung Jaya locations, which takes place within the scope of the Tulang Bawang River Basin.
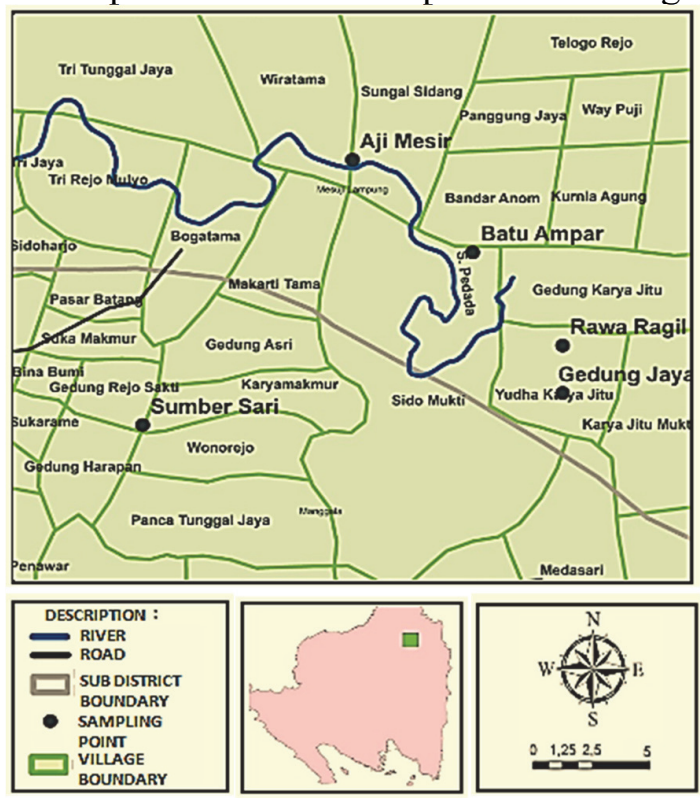

Fig. 1. Study area 
This research was carried out by conducting laboratory tests on soil samples and field observations on the reduction in height of flood embankments in the study area. The reduction in the height of the flood embankment to be reviewed is the settlement assumed to be caused by soil shrinkage, immediate decrease and decrease due to primary consolidation. The depth of soft soil around the study site was estimated using Cone Penetration Test. The steps undertaken to analyze the reduction in flood embankments and the time of decline are as follows:

\subsection{Calculation of decrease due to linear shrinkage}

Decrease in height of embankments due to linear shrinkage can be predicted by calculating the volumetric shrinkage by conducting shrinkage and moisture content tests. Following are some of the equations used in determining the shrinkage limit, volumetric shrinkage, shrinkage ratio and linear shrinkage.

\subsubsection{Shrinkage limit calculation}

$$
W_{s}=W-\frac{\left(V-V_{d}\right) \gamma_{w}}{W_{d}} \times 100 \%
$$

where,

$W_{S}=$ shrinkage limit

$W \quad=\quad$ the weight of the wet ground

$V \quad=\quad$ volume of wet soil

$V_{d} \quad=\quad$ dry soil volume

$\gamma_{\mathrm{w}}=$ unit weight of water content $\left(\mathrm{kg} / \mathrm{m}^{3}\right)$

$W_{d} \quad=\quad$ weight of dry soil

\subsubsection{Volumetric shrinkage calculation}

$$
V_{c}=\left(w_{0}-w_{s}\right) \times \frac{W_{d}}{V_{d} \gamma_{w}}
$$

in which,

$V_{c}=$ volumetric shrinkage

$w_{0}=$ initial water content

$w_{s}=$ shrinkage limit

$W_{d} \quad=\quad$ weight of dry soil

$V_{d} \quad=\quad$ dry soil volume

$\gamma_{\mathrm{w}}=$ unit weight of water content

\subsubsection{Linear shrinkage calculation}

$$
L_{s}=100 \times\left(1-\left[\frac{100}{V_{c}+100}\right]^{3}\right)
$$

where,

Ls = linear shrinkage

$V c=$ volumetric shrinkage

\subsubsection{Shrinkage ratio calculation}

$$
\mathrm{R}=\frac{V_{c}}{w_{0}-w_{s}}
$$


where,

$R=$ shrinkage Ratio

$V_{c}=$ volumetric Shrinkage

$w_{0}=$ initial water content

$w_{s} \quad=\quad$ shrinkage limit

2.2 Calculation of decrease due to linear shrinkage

$$
S_{i}=P \cdot B \cdot \frac{1-\mu^{2}}{E} I P
$$

where,

$S_{i}=$ immediate decline

$P I=$ evenly distributed load

$B=$ foundation width

$I P=$ influence factor

$\mu=$ Poisson ratio

$E=$ Young modulus

\subsection{Soil subsidence as a result of consolidation}

Pre consolidation pressure is the maximum overburden pressure that has ever occurred on the soil under test. If the Over Consolidation Ratio (OCR) value $<1$, then the land has consolidated (decreased). The OCR value is the ratio between the pre-consolidation pressure and the current overburden pressure. To calculate the decrease due to this consolidation, we need to determine the work load, which is the flood embankment load and the soft soil load reviewed. In general, the amount of consolidation that occurs is as follows:

$$
S=\frac{H C_{c}}{1+e_{0}} \log \frac{p_{1}^{\prime}}{p_{0}}
$$

$$
\begin{array}{lll}
\text { where, } & \\
S & = & \text { soil subsidence due to consolidation }(\mathrm{cm}) \\
H & = & \text { depth/height of land }(\mathrm{cm}) \\
e_{0} & = & \text { initial pore number } \\
C_{c} & = & \text { compression index } \\
p_{1} & = & \text { pre-consolidation pressure }=p_{0}+\Delta p \\
p_{0} & = & \text { effective overburden pressure before loading }
\end{array}
$$

\subsection{Time of consolidation}

At the end of the consolidation, the land was considered to have reached the degree of consolidation of $\mathrm{U} 90 \%$ with a $T_{v}$ time factor of 0.848 . This is because, after the primary consolidation there is actually still a decline up to $\mathrm{U} 100 \%$ with a $T_{v}$ value of infinite $(\approx)$. Time of consolidation can be determined based on the following equation:

$$
\mathrm{t}=\frac{T_{v} \cdot H_{d r}^{3}}{C_{v}}
$$

in which,

$\begin{array}{lll}t & = & \text { consolidation time (seconds) } \\ T_{v} & =\text { time factor } \\ H_{d r} & =\text { depth of soil under consideration for consolidation }(\mathrm{cm}) \\ C_{v} & =\text { consolidation coefficient }\end{array}$




\section{Results and discussions}

In this study, the results and discussion are a combination of laboratory test data, field measurements, calculation results and analysis, which consist of:

\subsection{Soil type, physical properties, clay content, and organic content}

Based on the Unified Soil Classification System (USCS) Method, three samples of type SC (Clayey Sand, sandy loam) and type CH (Fat Clay, loam with high plasticity) were tested. Whereas based on the United States Department of Agriculture (USDA) method (Soil Survey staff, 1993) the samples are clay type. The clay content is between $36.44 \%-79.94 \%$. The more downstream of the sample location the clay content of the sample tends to be greater. Organic content of the samples ranged from $11.38 \%$ $22.43 \%$ and was classified as clay or soft soils (MSRIRI, 2002). Table 1, illustrates the physical properties of the soils investigated in this research.

Table 1. Soil type, physical properties, clay content, and organic content

\begin{tabular}{lccccc}
\hline Physical properties & Aji Mesir & Sumber Sari & Gedung Jaya & Rawa Ragil & Batu Ampar \\
\hline Specific weight $(\mathrm{Gs})$ & 2.68 & 2.52 & 2.43 & 2.43 & 2.29 \\
Unit weight volume $\left(\mathrm{gr} / \mathrm{cm}^{3}\right)$ & 1.60 & 1.39 & 1.31 & 1.32 & 1.35 \\
Mass density $\left(\mathrm{gr} / \mathrm{cm}^{3}\right)$ & 1.61 & 1.35 & 1.32 & 1.37 & 1.40 \\
Pore number ('e) & 1.27 & 1.45 & 2.05 & 1.65 & 2.47 \\
Degree of saturation (\%) & 85.90 & 70.63 & 83.59 & 73.70 & 104.87 \\
Water content (\%) & 40.75 & 40.64 & 70.44 & 50.08 & 113.43 \\
Porosity (\%) & 57.68 & 60.79 & 68.48 & 63.77 & 72.34 \\
Silty clay (\%) & 36.44 & 46.53 & 47.69 & 53.97 & 79.94 \\
\hline
\end{tabular}

\subsection{Soil settlement}

To determine the amount of settlement and decrease due to shrinkage, it is necessary to conduct a shrinkage test. Volume changes due to shrinkage can be seen on the basis of volumetric shrinkage, shrinkage ratio, and linear shrinkage. Calculation of settlement of soil can be seen in Table 2 .

Table 2. Results of calculation of soil settlement

\begin{tabular}{lccccc}
\hline Physical properties & Aji Mesir & Sumber Sari & Gedung Jaya & Rawa Ragil & Batu Ampar \\
\hline Specific weight $(\mathrm{Gs})$ & 2.68 & 2.52 & 2.43 & 2.43 & 2.29 \\
Unit weight volume $\left(\mathrm{gr} / \mathrm{cm}^{3}\right)$ & 1.60 & 1.39 & 1.31 & 1.32 & 1.35 \\
Mass density $\left(\mathrm{gr} / \mathrm{cm}^{3}\right)$ & 1.61 & 1.35 & 1.32 & 1.37 & 1.40 \\
Pore number ('e) & 1.27 & 1.45 & 2.05 & 1.65 & 2.47 \\
\hline
\end{tabular}

Based on Table 2, it appears that the average volumetric shrinkage value of the sample is above $66.3 \%$. This is a significant change in soil volume compared to clay soils such as glacial fill, alluvial soil and Mio pliocene clays. The amount of linear shrinkage changes from $16.36 \%-19.08 \%$. With this range of linear shrinkage values, all samples can be considered nearly uniform with the $\mathrm{SC}$ and $\mathrm{CH}$ soil classifications. This linear shrinkage will later be used to determine the magnitude of the flood embankment reduction. The magnitude of the ratio between volumetric shrinkage and the range of the initial water content to the water level of the shrinking limit (shrinkage ratio) has values ranging from 0.85 to 1.37 . The relationship of the magnitude of changes in this volume to the range of initial water content to the level of water shrinkage forming a regression equation for volumetric losses, namely YV $=27.144 . \ln (\mathrm{X})-37.534$, with a value of $\mathrm{R}^{2}=0.9783$. Another equation that is formed is for linear shrinkage, namely $\mathrm{YL}=4.1918 . \ln (\mathrm{X})-0.3953$ with a value of $\mathrm{R}^{2}=0.9743 . \mathrm{X}$ itself is the range of initial water content to the limit of water content of shrinkage. In the form of a graph the relationship is explained in Fig. 2. 


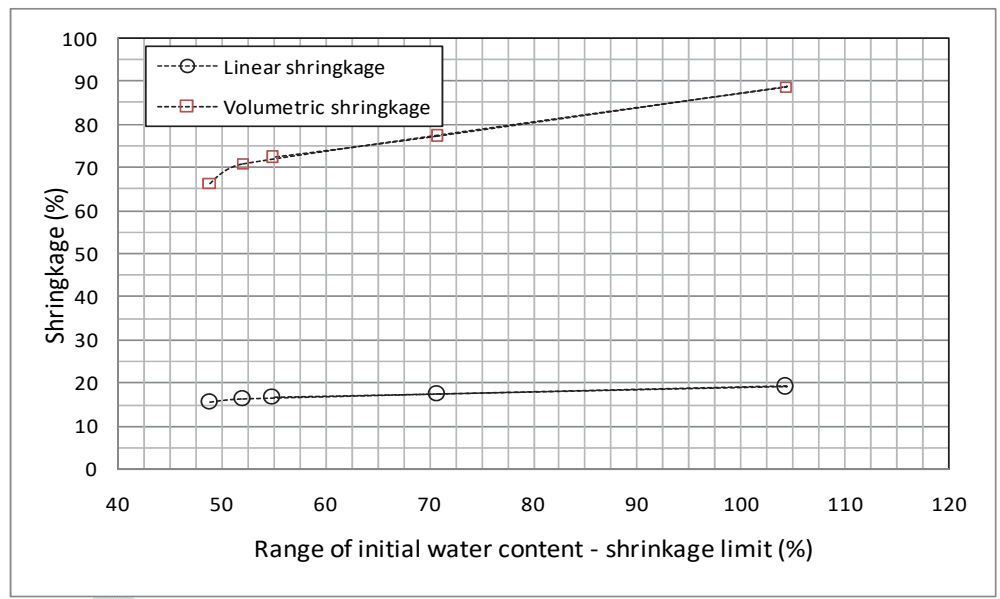

Fig. 2. Variations of shrinkage versus range of initial water content - shrinkage limit

Based on the graph above, it can be seen that the relationship between the change in linear shrinkage volume and the range of initial water content to the shrinkage limit gives a lower value compared to the relationship of the volumetric shrinkage change, which is around $20 \%$. Since the observed linear shrinkage is only changes in one dimension that results a change only in the elongated direction.

\subsection{The settlement of flood embankment}

The settlement that occurs due to linear shrinkage is obtained by multiplying the magnitude of the linear shrinkage to the initial embankment height for which data is obtained from the Public Works and Spatial Planning Office of Tulang Bawang Regency. These data are presented in Table 3.

Table 3. The calculation of settlement of embankment due to linear shrinkage

\begin{tabular}{ccccc}
\hline Sampling location & $\begin{array}{c}\text { Initial embankment } \\
\text { height }(\mathrm{cm})\end{array}$ & Linear shrinkage $(\%)$ & $\begin{array}{c}\text { The settlement due to } \\
\text { linear shrinkage }(\mathrm{cm})\end{array}$ & $\begin{array}{c}\text { Embankment height due } \\
\text { to linear shrinkage }(\mathrm{cm})\end{array}$ \\
\hline Aji Mesir & 150 & 15.59 & 23.39 & 126.62 \\
Sumber Sari & 350 & 16.36 & 57.26 & 292.74 \\
Gedung Jaya & 350 & 19.08 & 66.77 & 283.23 \\
Rawa Ragil & 200 & 17.37 & 34.73 & 165.27 \\
Batu Ampar & 180 & 16.58 & 29.85 & 150.15 \\
\hline
\end{tabular}

An immediate settlement is obtained by multiplying the load, foundation width, Poisson's ratior, foundation influence factor and divided by the young modulus value as given in Eq. (5). Load evenly distributed is obtained by multiplying the volume unit weight by the height of the embankment. Table 4 , illustrates the calculated values.

Table 4. The calculation of immediate settlement

\begin{tabular}{ccccccc}
\hline Sampling location & $\begin{array}{c}\text { Evenly } \\
\text { distributed load } \\
(\mathrm{P})\left(\mathrm{gr} / \mathrm{cm}^{2}\right)\end{array}$ & $\begin{array}{c}\text { Foundation } \\
\text { width }(\mathrm{B})(\mathrm{cm})\end{array}$ & Ip & $\begin{array}{c}\text { Poisson's } \\
\text { ratio }(\mu)\end{array}$ & $\begin{array}{c}\text { Young Modulus } \\
(\mathrm{E})\left(\mathrm{gr} / \mathrm{cm}^{2}\right)\end{array}$ & $\begin{array}{c}\text { Immediate } \\
\text { settlement }(\mathrm{cm})\end{array}$ \\
\hline Aii Mesir & 107.78 & 650 & 2.28 & 0.20 & $38,146.97$ & 8.93 \\
Sumber Sari & 217.35 & 1,050 & 2.36 & 0.20 & $38,146.97$ & 13.6 \\
Gedung Jaya & 213.68 & 1,050 & 2.36 & 0.20 & $38,146.97$ & 13.3 \\
Rawa Ragil & 123.50 & 750 & 2.78 & 0.20 & $38,146.97$ & 6.5 \\
Batu Ampar & 106.83 & 710 & 2.63 & 0.20 & $38,146.97$ & 5.0 \\
\hline
\end{tabular}

In the consolidation test, the OCR value $<1$ means that both the embankment and the soil under the embankment experienced a decrease in consolidation. The magnitude of settlement caused by consolidation on the embankment was obtained using Eq. (6). The calculation of consolidation on embankments is presented in Table 5 for different soils. 
Table 5. Calculation of consolidation on embankments

\begin{tabular}{cccccc}
\hline Sampling location & $\begin{array}{c}\text { Initial } \\
\text { embankment } \\
\text { height }(\mathrm{cm})\end{array}$ & $\begin{array}{c}\text { Initial pore } \\
\text { value }\left(\mathrm{e}_{0}\right)\end{array}$ & $\begin{array}{c}\text { Pore value due to } \\
\text { embankment load }\left(\mathrm{e}_{1}\right)\end{array}$ & $\Delta \mathrm{e}$ & $\begin{array}{c}\text { Settlement on embankments } \\
\text { due to consolidation }(\mathrm{cm})\end{array}$ \\
\hline Aji Mesir & 150 & 2.29 & 2.27 & 0.02 & 0.77 \\
Sumber Sari & 350 & 2.57 & 2.44 & 0.13 & 12.89 \\
Gedung Jaya & 350 & 2.74 & 2.62 & 0.12 & 11.21 \\
Rawa Ragil & 200 & 2.39 & 2.36 & 0.03 & 1.62 \\
Batu Ampar & 180 & 2.46 & 2.44 & 0.02 & 1.04 \\
\hline
\end{tabular}

The value of soil consolidation under the embankment can be determined based on Eq. 7, and the results are presented in Table 6.

Table 6. The settlement due to consolidation of soils under the embankments

\begin{tabular}{ccccccc}
\hline Sampling location & $\begin{array}{c}\text { The height of } \\
\text { soft soil }(\mathrm{H}) \\
\text { in } \mathrm{cm}\end{array}$ & $\begin{array}{c}\text { Load of } \\
\text { embankment } \\
(\Delta \mathrm{P}) \text { in gr/cm }\end{array}$ & $\begin{array}{c}\text { Load of soil under } \\
\text { the embankment } \\
\left(\mathrm{P}_{0}\right) \text { in }\left(\mathrm{gr} / \mathrm{cm}^{2}\right)\end{array}$ & $\left(\mathrm{C}_{\mathrm{c}}\right)$ & $\left(\mathrm{e}_{0}\right)$ & $\begin{array}{c}\text { Consolidation on the } \\
\text { soil under the } \\
\text { embankment }(\mathrm{cm})\end{array}$ \\
\hline Aji Mesir & 1.080 & 240 & 398.93 & 0.14 & 1.27 & 16.54 \\
Sumber Sari & 1.140 & 486 & 356.22 & 0.08 & 1.45 & 9.04 \\
Rawa Ragil & 1.820 & 264 & 490.37 & 0.17 & 1.65 & 40.23 \\
Batu Ampar & 1.840 & 243 & 341.22 & 0.36 & 2.47 & 44.33 \\
\hline
\end{tabular}

If the total settlement due to linear shrinkage, immediate settlement and consolidation, is compared to the settlement that occurred on the embankment in the field, there will be a uniform difference as in Table 7. This means that the results of the calculation of the settlement of embankment in the study area are valid and true. However, quite different results were produced by sampling from Gedung Jaya. Therefore the calculation for the Gedung Jaya sample is not continued because it is considered as invalid data. Fig. 3 illustrates the contribution of each settlement in each sampling location.

Table 7. Difference of theoretical embankment height and real embankment height (field measurements)

\begin{tabular}{ccccc} 
Sampling location & $\begin{array}{c}\text { Initial height of } \\
\text { embankment }(\mathrm{cm})\end{array}$ & $\begin{array}{c}\text { Height of embankment } \\
\text { after consolidation }(\mathrm{cm})\end{array}$ & $\begin{array}{c}\text { Theoretical height of } \\
\text { embankment after } \\
\text { consolidation }(\mathrm{cm})\end{array}$ & $\Delta$ \\
\hline Aii Mesir & 150 & 95 & 100.38 & $5.66 \%$ \\
Sumber Sari & 350 & 260 & 240.44 & $7.52 \%$ \\
Rawa Ragil & 200 & 115 & 109.59 & $4.70 \%$ \\
Batu Ampar & 180 & 90 & 93.38 & $3.75 \%$ \\
\hline
\end{tabular}

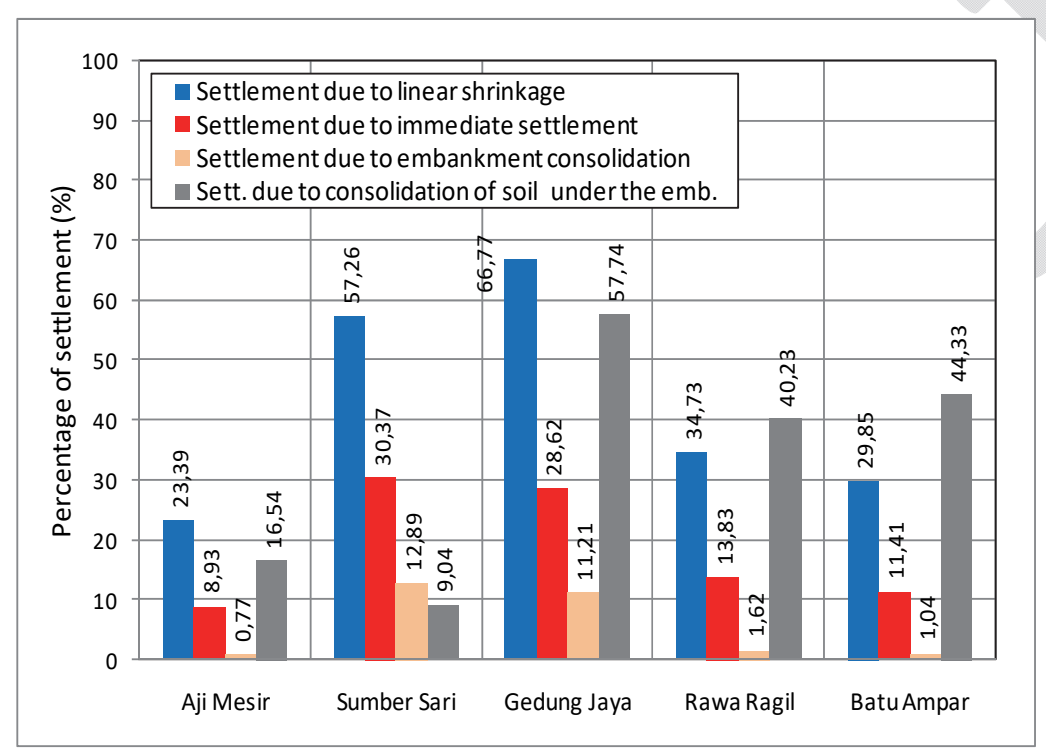

Fig. 3. Contribution of each settlement to the total settlement in each sampling point 
The contribution of each type of settlement to the total embankment settlement is presented in Fig. 4. The figure shows that the main cause of total settlement in the embankment is the settlement due to linear shrinkage. It contributes around $42.51 \%$ of total settlement. The next cause of the dike reduction is the consolidation of soil under the embankment, which contributes of $34.48 \%$ of total settlement. Furthermore, the cause of the settlement in the embankment was an immediate settlement which contributes around $18.32 \%$ of total settlement. The type of settlement that contributes the smallest on the total settlement of the embankment was the settlement of the embankment themselves, which was around $4.62 \%$ of total settlement.

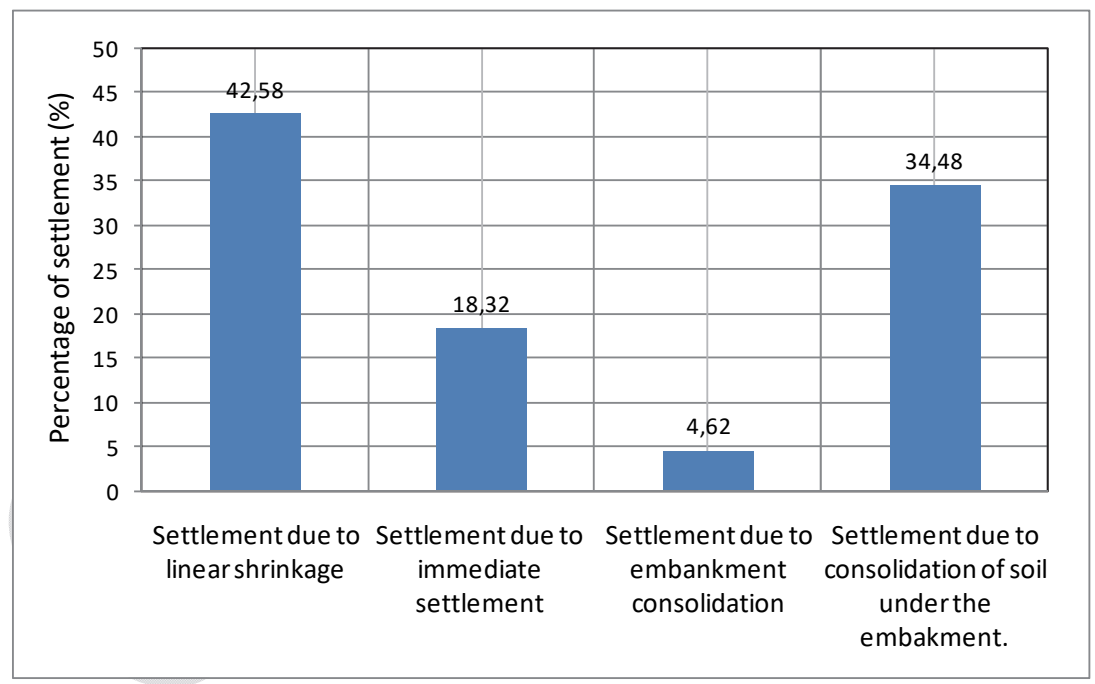

Fig. 4. Contribution of each type of settlement on the total settlement

\subsection{The settlement of flood embankment}

The time of consolidation is the time required for the soil to become compressed by removing the soil pore water due to loading. The time of consolidation of the embankment and the underlying soil is calculated based on Eq. (7) and is presented in Table 8. Based on Table 8, it can be seen that the consolidation time occurring on the embankment is much shorter, which ranges from 0.58 to 1.82 months, when compared to the consolidation time on land under the embankment, which is between 5.25 and 29.15 months. This may occur due to the height of the embankment layer is shorter when compared to the one of the underlying soil layers.

Table 8. Consolidation time values based on the calculation

\begin{tabular}{lcccccc}
\hline \multirow{2}{*}{$\begin{array}{c}\text { Sampling } \\
\text { location }\end{array}$} & \multicolumn{3}{c}{ Embankment } & \multicolumn{3}{c}{ Soil under the embankment } \\
\cline { 2 - 7 } & $\begin{array}{c}\text { Embankment } \\
\text { height } \\
(\mathrm{cm})\end{array}$ & Consolidation $(\mathrm{cm})$ & $\begin{array}{c}\text { Time } \\
(\mathrm{month})\end{array}$ & $\begin{array}{c}\text { The depth } \\
\text { of soft soil }(\mathrm{cm})\end{array}$ & Consolidation $(\mathrm{cm})$ & $\begin{array}{c}\text { Time } \\
(\mathrm{mon} t \mathrm{n})\end{array}$ \\
\hline Aji Mesir & 150 & 0.77 & 1.30 & 1,080 & 16.54 & 22.45 \\
Sumber Sari & 350 & 12.89 & 1.82 & 1,140 & 9.04 & 5.25 \\
Rawa Ragil & 350 & 1.62 & 0.58 & 1,980 & 40.23 & 12.04 \\
Batu Ampar & 200 & 1.04 & 1.12 & 1,820 & 44.33 & 29.15 \\
\hline
\end{tabular}

In order to find out whether the current dike has reached its consolidation time, we need to compare the time span since the dike was made with its consolidation time. Based on Table 9, it appears that the consolidation process has been completed on the embankment Aji Mesir, Sumber Sari, and Rawa Ragil. On the other hand, the consolidation process at the Batu Ampar embankment is still in process. 
Table 9. The condition of consolidation process at consolidation time (T90, i.e. Consolidation at time of $90 \%$ consolidation process)

\begin{tabular}{|c|c|c|c|c|c|c|}
\hline $\begin{array}{c}\text { Sampling } \\
\text { location }\end{array}$ & $\begin{array}{c}\text { Existing } \\
\text { embankment } \\
\text { height } \\
(\mathrm{cm}) \\
\end{array}$ & $\begin{array}{c}\text { Theoretical } \\
\text { embankment } \\
\text { height } \\
(\mathrm{cm})\end{array}$ & $\Delta(\%)$ & $\begin{array}{l}\text { The time needed } \\
\text { for consolidation } \\
\text { (observations) (month) }\end{array}$ & $\begin{array}{l}\text { The time needed ( } \\
\text { for consolidation } \\
\text { (calculation) } \\
\text { (month) }\end{array}$ & $\begin{array}{l}\text { nsolidation time } \\
\text { T90 }\end{array}$ \\
\hline Aji Mesir & 127,32 & 132,70 & $4,22 \%$ & 67 & 22,45 & Reached \\
\hline Suml & 347,63 & & $5,63 \%$ & 44 & 5,25 & Reacl \\
\hline Rawa Ragil & 163,56 & 158,15 & $3,31 \%$ & 40 & 12,04 & Reached \\
\hline Batu Ampar & 131,25 & 134,63 & $2,57 \%$ & 17 & 29,15 & Unreached \\
\hline
\end{tabular}

A decrease in embankment due to linear shrinkage and an immediate decrease are assumed to occur simultaneously and occur immediately since the embankment was made. Whereas the decrease of embankment and the soil under the embankment due to its consolidation will follow the time of its consolidation, although actually the soil will continue to become incompressible in its secondary consolidation which is smaller and slower, until it reaches plastic deformation of soil particles. The ratio between the percentage of embankment reduction and time in the Rawa Ragil and Batu Ampar areas is greater than the one in Aji Mesir and Sumber Sari. This might have happened because Rawa Ragil and Batu Ampar are located in the downstream area which has deeper soft soil layers, which is between 1.82 to $1.84 \mathrm{~m}$. While Aji Mesir Aji Region and Sumber Sari are located in the upper reaches of the river which has a depth of soft soil layers between 1.08 to $1.14 \mathrm{~m}$. This condition results in two types of curve of ratio between the percentage of embankment reduction and time, for sampling locations in the upstream and downstream area of the river as illustrated in Fig. 5. The curves are produced by regression equation as follows:

$$
\begin{array}{ll}
Y_{1}=0.0163 \cdot \ln (X)+0,2703 & \text { for upstream area } \\
Y_{2}=0.0512 \cdot \ln (X)+0,2987 & \text { for downstream area }
\end{array}
$$

in which,

$\mathrm{Y}_{1}$ : ratio between existing height of embankment to the initial height of embankment for area located in upstream of the river (\%).

$\mathrm{Y}_{2}$ : ratio between existing height of embankment to the initial height of embankment for area located in upstream of the river $(\%)$.

$\mathrm{X}:$ time of consolidation (month)

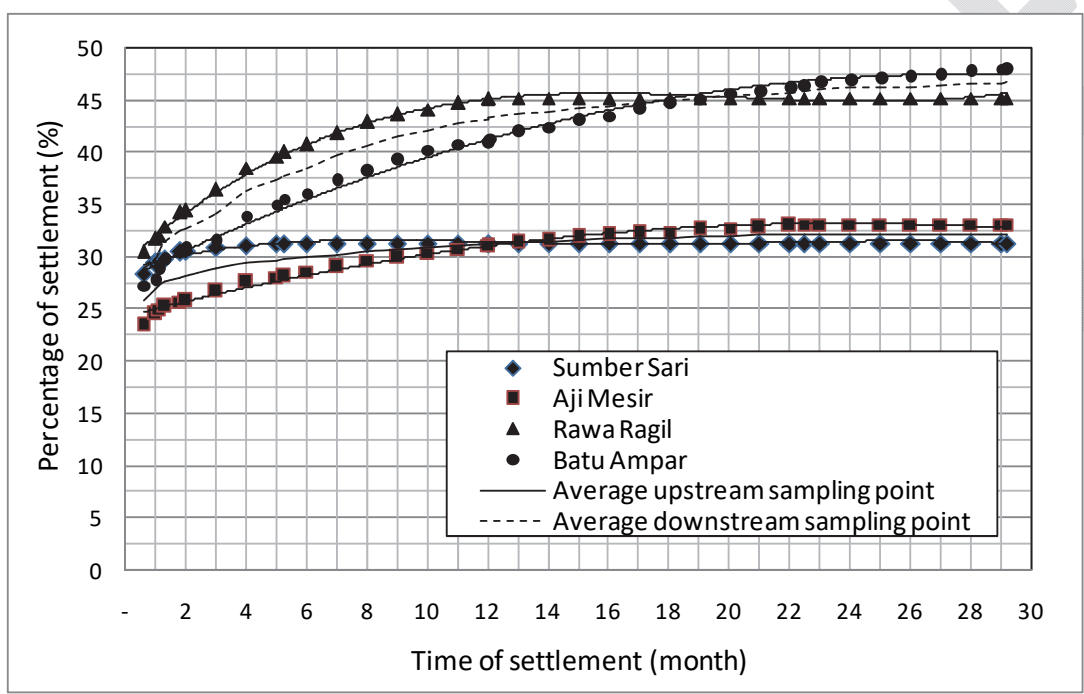

Fig. 5. Relationship of the percentage of settlement and time. 


\section{Conclusions}

Case studies of embankment decline in swampy areas due to shrinkage and consolidation in the Tulang Bawang watershed were investigated and analyzed. The study provides the following conclusions:

1. Linear shrinkage contributes between $16.36 \%-19.08 \%$ of the total decrease. This range of linear shrinkage occurs in all types of investigated soils. The value of reduction based on calculations due to linear shrinkage in embankment samples in the field was ranged from $23.39-66.77 \mathrm{~cm}$.

2. The relationship between changes in the linear direction (YL) with the difference between the water content of the shrinkage limit and the initial water content $(\mathrm{X})$ forms a regression equation $\mathrm{YL}=4.1918 . \ln (\mathrm{X})-0.3953$ with a value of $\mathrm{R}^{2}=0.9743$.

3. Linear shrinkage gives the biggest contribution in decreasing total embankment. Next in a row, from large to small, is the consolidation of land under the embankment, immediate decline, and consolidation on the embankment.

4. The time of consolidation on embankments is much shorter than the time of consolidation of soils under embankments. The relationship between the percentages of embankment decreases with time was stated by two regression equations for the sample location in the downstream and upper river regions.

\section{Acknowledgements}

The authors would like to express their highest gratitude and appreciation to the Civil Engineering Faculty of Lampung University and to the Lab technicians for their help and support in the implementation and completion of this paper.

\section{References}

Afriani, L., Adha, I., Juansyah, Y., \& Febrina, R. (2020). Modification Compression Strength of Test Machine by Using Control System on Compaction Energy. MS\&E, 807(1), 012008.

Afriani, L. (2014). Soil Shear Strength, Jakarta: Graha Ilmu Publisher.

Das, B.M. (1995). Soil Mechanic, Geotechnique Principle. Jakarta: Erlangga.

Izdebska-Mucha, D., \& Wójcik, E. (2013). Testing shrinkage factors: comparison of methods and correlation with index properties of soils. Bulletin of Engineering Geology and the Environment, 72(1), 15-24.

Kumor, M. (2008). Selected geotechnical problems of expansive clays in the area of Poland. Architecture Civil Engineering Environment, 1(4), 75-92.

Ministry of Settlement and Regional Infrastructure of the Republic of Indonesia (MSRIRI) (2002). Process of formation and basic properties of soft soil. Bandung: Guidelines for Regional Infrastructure Research and Development Center No: Pt T-8-2002-B.

Muntohar, A.S. (2005). Introduction to Geotechnique. Yogyakarta: University Muhammadiyah Jogja Soil Mechanics Lab.

Public Works and Spatial Planning Office, Tulang Bawang Regency (2016). Data Base Jaringan Irigasi Rawa Kabupaten Tulang Bawang. Tulang Bawang: Water Resources Division.

Soil Survey Division Staff (1993). Soil Survey Manual: US Dept. Agriculture Handbook No. 18. Washington DC:United State Department of Agricultural.

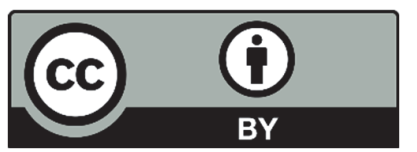

(C) 2021 by the authors; licensee Growing Science, Canada. This is an open access article distributed under the terms and conditions of the Creative Commons Attribution (CC-BY) license (http://creativecommons.org/licenses/by/4.0/). 